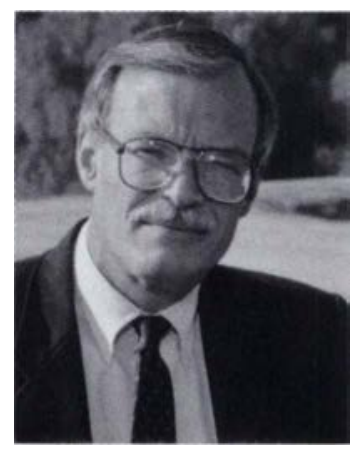

\section{Future trends challenge irrigated agriculture}

Henry J. Vaux, Jr.

Associate Vice President

Agriculture and Natural Resources

$\mathrm{T}$ he floods of 1996-97, which have cost California agriculture several hundred million dollars in damages, remind us once again that irrigated agriculture is subject to external events that profoundly affect those who farm and those who depend upon farming (see p. 4). Coping with floods, droughts and other natural disasters is always difficult, in part, because these events are hard to predict. Although it is sometimes equally difficult to foresee economic and policy changes, new reports from the Council for Agricultural Science and Technology (CAST) and the National Research Council (NRC) contain similar findings and conclusions about the future of irrigated agriculture ${ }^{1}$.

Throughout much of the past century, irrigated agriculture has existed in an environment characterized by supportive governmental policies, relatively abundant supplies of good quality water and generally favorable economic conditions. The authors of the CAST and NRC reports conclude that irrigated agriculture will likely find itself in sharply different circumstances during the next 10 years. The two reports identify a number of changes with which irrigated agriculture is likely to be confronted in the 21st century:

- Irrigated agriculture that is dependent on persistent ground water overdraft will be threatened. For both economic and environmental reasons, it will be extremely difficult to develop supplemental sources of surface water to offset the overdraft and water scarcity will intensify.

- Irrigated agriculture in California and throughout the West will face increasing competition for developed water supplies from both the urban and environmental sectors. Irrigated agriculture will be seen as an attractive supplier for new urban and environmental uses. This is true both because agriculture uses a large proportion of the developed water supply $-75 \%$ in California, more elsewhere - and because the value of water at the margin for most urban uses and some environmental uses is higher than for agricultural uses.

- Government policies are likely to be less favorable to irrigated agriculture in the future than they have been in the past. Federal water policies, which were extremely important in helping to establish irrigated agriculture on its present scale in the West, increasingly devolve responsibility for water management and development to the states. Simultaneously, federal environmental policies are becoming stricter and exemptions from some policies for agriculture may disappear. Similarly, future federal agricultural policies are likely to be less favorable to irrigated agriculture than in the past. Crop price supports have been uncoupled from production and subsidies are scheduled to end in 2002. Although future policies will not accord the special treatment of the past to agriculture, there is no expectation that they will be hostile.
- Even as water supplies become more constrained and public policies become less favorable, irrigated agriculture will be increasingly subject to the pressures of a globalizing agricultural economy. Agricultural trade liberalization of the type made possible by NAFTA and the Uruguay Round of GATT will become more the rule. Growers will have to be increasingly flexible, adaptive and innovative to survive.

The authors of both studies are generally optimistic about the prospects for adapting to these sweeping changes. But they conclude that in the future irrigated agriculture will likely have to be more environmentally friendly, use less water, and be highly productive. It is instructive that both reports emphasize the importance of research and development in responding to the challenges of the future. The CAST report notes that the ease with which western growers adapt to future economic and policy changes is likely to be related directly to levels of investment in agricultural research and development. The NRC report states that: “. . research and teaching ... will need to be innovative in integrating, interpreting and disseminating information; be more global in perspective; and recognize the intense pressures associated with operating irrigated farms in the modern and environmentally conscious context."

Public investment in agricultural research and extension has yielded high returns that are unmatched in other industries over comparable periods. Yet, such public investment has been falling in real terms and the outlook suggests further declines. If irrigated agriculture is to compete successfully in the emerging global economy while operating in more environmentally friendly ways and reducing demands on natural resources, the trend of declining investment in agricultural research and extension will have to be reversed. Strong support for increased levels of public investment in agricultural research and outreach will be extremely important, but it may not be realistic to expect federal, state and local government to bear all of the increased costs in times of fiscal stringency and retrenchment. If research and extension are to be conducted on a scale appropriate to the challenges of the future, those who benefit from this research and extension will have to provide more financial support for those activities than they have in the past. The Division of Agriculture and Natural Resources and those whom it serves will need to form new partnerships to ensure that California growers can respond quickly and effectively to the challenges which characterize the future of irrigated agriculture.

${ }^{1}$ Council for Agricultural Science and Technology. 1996. Future of Irrigated Agriculture. Task Force Report No. 127 (Council for Agricultural Science and Technology: Ames, lowa).

National Research Council. 1996. A New Era for Irrigation. (Washington, D.C.: National Academy Press) 